\title{
A Bioaugmentation Agent in Super Intensive Marine Shrimp Farming System with Zero Water Exchange
}

\author{
Salência HR, Mouriño JLP*, Ferreira GS, Arantes RF, Ubert M, Lapa KR and Seiffert WQ
}

Laboratory of Marine Shrimp, Department of Aquaculture, Federal University of Santa Catarina, Brazil

\begin{abstract}
This study evaluated the feasibility of using Comambio ${ }^{\circledR}$, commercial product for bioremediation, in superintensive system of Litopenaeus. vannamei with zero water exchange. First, the concentration was determined to bioaugmentation on the settleable solids (SSed) in water containing microbial flakes. The second stage consisted in testing the application frequency in weekly and biweekly basis upon performance of shrimp. Were described physical and chemical parameters of water quality in the treated trial and that without application. The concentration of 0.56 $\mathrm{g} / \mathrm{L}$ was selected by reducing significantly $(\mathrm{p}<0.05)$ the SSed value. The frequency of weekly application promoted the chance of livelihood and increased the final biomass growth of the shrimp by $46.6 \%$ of growth rate, $17.0 \%$ in the final biomass and $10.23 \%$ of livelihood with regard to the control sample. Eventually, there was a dramatic drop in the SSed $(63.4 \%)$ with Comambio ${ }^{\circledR}$ while the total suspended solids increased with the suspended fixed solids. On the other hand, the biochemical oxygen demand showed the least value, Comambio ${ }^{\circledR}$ and control, $70.2 \%$ and $17.4 \%$ respectively. Summing up the bioaugmentation agent declined the value of SSed, contributing to the growth and reducing feed conversion as well as the final livelihood biomass of the shrimp cultivation system. The total average gain in weight per fish was higher in the automatic feeding $(89.50 \mathrm{~g})$ than in manual $(78.50 \mathrm{~g})$. An FE of $20.9 \%$ was obtained in the automatic feeding and $18.6 \%$ in manual, in relation to their FCRs. A t-test, conducted at $5 \%$ significance level, indicated a significant difference in the two feeding methods.
\end{abstract}

Keywords: Wastewater shrimp; Bioremediation; Pacific white shrimp; Sustainable shrimp; Environmental degradation

\section{Introduction}

The increasing demand of food consumption and improving the food security system have led to aquaculture development worldwide. FAO [1] predicts that this industry is likely to boom in the near future due to world population growth. The decline of the fishing industry has demanded underlining challenges to fish farming practices in order to ensure the availability of fish as an important source of protein. On the other hand, the aquaculture industry has responded to a number of environmental challenges such as water shortage and quality, land degradation, high costs of land hiring, environmental impact and diseases that has promoted the development of intensive aquaculture crop oriented $[2,3]$.

The super-intensive culture system with marine shrimp is a response to the need for increased production in places where water and land are limited. Therefore, there is a need to maintain the bio-security in spaces contaminated by diseases, especially in already endangered areas [4-8].

In these systems the microbial degradation of organic waste is responsible for the maintenance of water quality parameters suitable for the cultivation of penaeid shrimp $[9,10]$. Nevertheless, at high stocking densities, the water column has a limited capacity for self-purification [11]. Bioaugmentation is a bioremediation strategy that consists in the introduction of microorganisms and/or its metabolites in the polluted environment that accelerates the removal of unwanted biodegradation contaminants [12].

The external charge of beneficial microorganisms to the aquaculture cropping system is crucial to increase the capacity for self-purification as well as to improve the water quality, which is suitable for animal growth within the farming system [11]. The usage of commercial bioaugmentation agents containing bacteria of the genus Bacillus sp. Nitrosomonas sp. Nitribacter sp. and Lactobacillus in intensive cultivation of marine shrimp Penaeus monodon and L. vannamei increased the survival and reduced considerably the concentrations of Vibrio sp., total organic carbon and total nitrogen in waters of cultivation $[13,14]$.

This study evaluated the feasibility of using Comambio ${ }^{\circledR}$, commercial product for bioremediation treatment of domestic sewage in super intensive culture of L. vannamei in microbial flakes system with zero water exchange.

\section{Materials and Methods}

Three subsequent tests were conducted to evaluate the feasibility of applying Comambio ${ }^{\circledR}$ in super intensive cropping systems in the pacific white shrimp with zero water exchange. The first step examined the dosage of Comambio ${ }^{\circledR}$ to be applied in systems with super intensive with microbial flakes on the reduction of settleable solids (SSed) microbial flakes used in marine shrimp cultivation schemes. After setting the concentration to be utilized, the frequency of use of the commercial bioaugmentation agent was evaluated on the production performance in marine shrimp grown in super intensive system with microbial flakes. The last test aimed to characterize the effects of Comambio ${ }^{\circledR}$ on the physical and chemical variables of water quality in super intensive microbial flakes farming system.

*Corresponding author: Mouriño JLP, Laboratory of Marine Shrimp, Department of Aquaculture, Federal University of Santa Catarina, Brazil, Tel: +5548 37210416 E-mail: jose.mourino@ufsc.br

Received September 28 2015; Accepted December 30, 2015; Published February 15, 2016

Citation: Salência HR, Mouriño JLP, Ferreira GS, Arantes RF, Ubert M, et al (2016) A Bioaugmentation Agent in Super Intensive Marine Shrimp Farming System with Zero Water Exchange. J Aquac Res Development 7: 406. doi:10.4172/21559546.1000406

Copyright: (c) 2016 Salência HR, et al. This is an open-access article distributed under the terms of the Creative Commons Attribution License, which permits unrestricted use, distribution, and reproduction in any medium, provided the original author and source are credited. 
The test used Comambio ${ }^{\circledR}$ which has in its formulation the following microorganisms: the Bacillus cereus, B. amyloquifaciens and B. subtilis at concentrations of $6.17 \times 10^{5} \mathrm{CFU} / \mathrm{mL}$; whereas the concentration of $9.00 \times 10^{3} \mathrm{CFU} / \mathrm{mL}$ the microorganisms are the following: Geotrichum sp., Aspergillus niger, Penicillium sp., Mycelia sterile and Trichoderma koningii; for B. brevis and Corynecacterium sp. the concentration was $1.00 \times 10^{5} \mathrm{CFU} / \mathrm{mL}$. The Trades Comambio ${ }^{\circledR}$ and Bioremediation Services Ltda. [15] Company provided the concentrations of the microorganisms.

To help understanding the reactions of the product Comambio ${ }^{\circledR}$ system with super intensive cultivation microbial flakes, physical and chemical analysis of $0.56 \mathrm{~g}$ were performed in $1 \mathrm{~L}$ of sea water autoclaved at $120^{\circ} \mathrm{C}$ temperature and $3.2 \mathrm{~g} / \mathrm{L}$ salinity, in terms of $\mathrm{pH}$, alkalinity, total suspended solids (TSS), fixed suspended solids (FSS), volatile suspended solids (VSS), total organic carbon (TOC) and biochemical oxygen demand (BOD), without adding bioflocs. The bioaugmentation Comambio ${ }^{\circledR}$ agent was kept in a cold camera at $22^{\circ} \mathrm{C}$ until used throughout the experimental period.

The totals of 540 shrimp were used (of $1.66 \pm 0.10 \mathrm{~g}$ ) to evaluate the effect of the product Comambio ${ }^{\circledR}$ on production and performance of the shrimp. In a separated experiment 1200 shrimp with average weight of $20.62 \pm 0.39 \mathrm{~g}$ to characterize the effects of Comambio ${ }^{\circledR}$ in physical and chemical variables of water. All shrimp used in this experiment were from the Marine Laboratory of Shrimp in the Federal University of Santa Catarina, the resulting from F1 offspring, from SPF breeders and free of pathogens $\left(\right.$ Genearch $^{\circledR}$, Brasil). The shrimp were kept in seawater until there were used without microbial flakes, at $28^{\circ} \mathrm{C}$ of temperature and $3.2 \mathrm{~g} / \mathrm{L}$ of salinity.

Eight Comambio ${ }^{\circledR}$ concentrations $(0.0,0.11,0.22,0.33,0.44,0.56$, $0.67,0.78,0.89 \mathrm{~g} / \mathrm{L}$ ) were tested in water containing microbial flakes with the initial level of around $8.0 \mathrm{~mL} / \mathrm{L}$ SSed, taken from the super intensive cultivation of shrimp microbial flakes previously prepared.

The experimental design was randomized using nine treatments and four replicates. Plastic bottles of $1.5 \mathrm{~L}$ (conical cylinder) were used. Water without application of the product was used for the control group. Aeration and temperature were kept constant at $27^{\circ} \mathrm{C}$ with heated titanium Scam ${ }^{\circledR} 500 \mathrm{~W}$ to maintain the suspended particulate matter. To determine the effect of concentration, there were measured once a day SSed using cones of Innoff [16].

\section{Experiment 1}

This test evaluated the effect of frequency of use and application of the bioaugmentation Comambio ${ }^{\circledR}$ on growth performance of juvenile shrimp grown in super intensive system with microbial flakes. The frequency of application was divided as to the weekly and biweekly applications seeking to define the toxicity of the existence of animals reared on the continued use of the agent.

The experimental outline was randomly sorted with three different treatments and four repetitions each: Product application every week (weekly), every two weeks (biweekly) and without application of bioaugmentation agent (control). The concentration of the applied bioaugmentation was pre-defined.

Thirty-six experimental of conical cylinder of fiberglass with a capacity of $25 \mathrm{~L}$ were used, stocked with 45 juveniles of $L$. vannamei showing initial weight $1.66 \pm 0.01 \mathrm{~g}$. During the 21 day experimental period, the shrimp were fed with commercial feed (40 Potima J, Guabi $^{\circledR}$ ), $40 \%$ protein, report lipid level) at a rate of $5 \%$ of the total biomass in each tank, divided into three equal portions daily following recommendations supported [17]. The temperature and dissolved oxygen were monitored and maintained at appropriate levels through SACAMA $^{\circledR}$ titanium heaters of $500 \mathrm{~W}$ and controlled by thermostat and using aeration and constant enough to keep any suspended particles. At the end of the experiment, growth, survival, biomass and food conversation was assessed for each treatment.

\section{Experiment 2}

The experiment was randomly designed with two treatments and six replicates, with application of Comambio ${ }^{\circledR}$ and without (control). There were 12 experimental units of the circular fiberglass with $1.1 \mathrm{~m}^{2}$ and 900 L capacity each. The water used to supply the experimental units was taken from a tank of super-intensive shrimp cultivation with microbial flakes already established assuring that all the tanks were under same conditions of water quality at the beginning of the experiment.

Water temperature and dissolved oxygen were kept constant with the aid of titanium heaters $\mathrm{Scam}^{\circledR} 1000 \mathrm{~W}$ controlled by thermostats and sufficient aeration in the quest to keep the suspended particulate matter. On the other hand, the concentration of oxygen dissolved in appropriate values for the growth of the animals were monitored using YSI 55 digital oximeter three times daily.

Shrimp with an average weight of $20.62 \pm 0.39 \mathrm{~g}$ were kept in these units until they reached final weight of $24 \mathrm{~g}$. The density in the stand was $120 \mathrm{shrimp} / \mathrm{m}^{3}$ and the experiment lasted 30 days. Commercial feed was provided with 35 EXT Potima Guabi ${ }^{\circledR}$ (35\% Protein). The feeding rate was $1.7 \%$ of the biomass in each experimental unit, given in equal portions of three times a day, following recommendations [17]. At the end of the experiment, growth, survival, biomass and food conversation was assessed for each treatment. Ssed were determined by gravimetric method using volumetric Innoff cones as described by AMERICAN PUBLIC HEALTH ASSOCIATION [16].

In the Experiment 1 alkalinity and hydrated lime was added to all tanks when its value was less than $120 \mathrm{mg} / \mathrm{L}$ according to the amounts proposed by Ebeling et al. [18]. The concentration of toxic nitrogen compounds (ammonia and nitrite) in Experiment 2, as well as orthophosphate was monitored with the methods described in AMERICAN PUBLIC HEALTH ASSOCIATION [16]. The solids serial like a TSS, SSV and SSF was determined weekly the according to APHA [19] by method 2540D and 2540E. The temperature was measured using YSI 55 field thermometer, dissolved oxygen $\left(\mathrm{O}_{2}\right)$ using YSI 55 digital Oximeter in Experiment 1 and 2. These data were evaluated daily in the morning and evening. In Experiment $2 \mathrm{pH}$ was measured using YSI 30 digital $\mathrm{pH}$ meter, for transparency, Secchi disk were used. All measurement was done daily. BOD and TOC were determined at the beginning and the end of the experiment using the methods proposed by AMERICAN PUBLIC HEALTH ASSOCIATION [16] - 5210B and [16] - 52310D, respectively.

\section{Bacteriological analysis}

The determination of concentrations of total heterotrophic bacteria and water Vibrionaceae was held at the beginning and end of the experiment 1 and 2 of the project. Water samples were seeded on petri plates with agar Thiosulfate-Citrate-Bile-Sucrose and Marine Agar and incubated at $35^{\circ} \mathrm{C}$ for $24 \mathrm{~h}$ before the count according to Madigan et al. [20]. Each water sample was analyzed in triplicate.

\section{Statistical analysis}

Data were analyzed using the program STATISTIC ${ }^{\circledR}$ version 7.0. 
Concentration of the Comambio ${ }^{\circledR}$ was defined by simple regression significance at $1 \%$ and then analysis of variance was performed by ANOVA test followed by comparison of means by Tukey test at $5 \%$ significance between the values obtained.

The data resulting of the Experiment I were assessed for normality, and once detected, Bartlet test was applied to the investigation of variances homoscedasticity. Data were transformed to $\log (\mathrm{x}+1)$ and subjected to analysis of variance $(\alpha=5 \%)$ where was not homogeneity. The Tukey test was performed in cases of a statistically significant difference comparison of means [21]. The Student's t-test was used to investigate the significant differences $(\alpha=5 \%)$ for the data obtained Experiment 2 [21]. Additionally, the confidence interval was calculated in the means resulting from the total counts of heterotrophic bacteria and vibrios present in the samples with levels of significance of $5 \%$.

\section{Results}

\section{Comambio $^{\circledR}$ features}

The data in sea water "crystal", and $3.2 \mathrm{~g} / \mathrm{L}$ salinity showed $\mathrm{pH} 8.2$, alkalinity $126 \mathrm{mg} / \mathrm{L} \mathrm{CaCO}_{3}, 574.5 \mathrm{mg} / \mathrm{L}$ TSS, 495, $0 \mathrm{mg} / \mathrm{L} \mathrm{SSF}, 79.5$ $\mathrm{mg} / \mathrm{L} \mathrm{SSV} ; 2.0$ BOD, $2.0 \mathrm{mg} / \mathrm{L}$ COD, TOC $1.8 \mathrm{mg} / \mathrm{L}$.

Significant linear relationship was observed $(\mathrm{p}<0.01)$ between the concentration of Comambio ${ }^{\circledR}$ SSed in water and super intensive shrimp cultivation, Figure 1, described by the equation $y=-3.3439 x+8.9882$, $\mathrm{R}^{2}=0.889$. The increased concentration of Comambio ${ }^{\circledR}$ increased the volume reduction SSed. There was also found that from 0.56 to 0.89 $\mathrm{mL} / \mathrm{L}(\mathrm{SSed}=6.50,6.62,6.37$ and $5.87 \mathrm{~mL} / \mathrm{L})$, Comambio ${ }^{\circledR}$ showed a greater effect in reducing SSed compared to the Control group, 8.93 $\mathrm{mg} / \mathrm{L}$. The line " $\mathrm{Z}$ " in Figure 1 is the reference that corresponds to the lower end of the confidence interval of the mean of control at 5\% confidence level. SSed values below the reference line are statistically lower than the values above the line $(\mathrm{p}<0.05)$. The concentration of 0.56 $\mathrm{mL} / \mathrm{L}$ Comambio ${ }^{\circledR}$ was identified as a benchmark for the reduction of $13 \%$ SSed be the minimum and with significantly reduced SSed.

The weight gain and final biomass in Experiment 1 were higher in treatments with Comambio ${ }^{\circledR}, 1.52 \pm 0.14 \mathrm{~g}, 361.01 \pm 15.95 \mathrm{~g}$ and 1.57 $\pm 0.29 \mathrm{~g}$ and $351.34 \pm 30.06 \mathrm{~g}$ for weekly and fortnightly treatments respectively, compared with control which was $1.07 \pm 0.02 \mathrm{~g}$ and 308.41 $\pm 38.37 \mathrm{~g}$ for weekly weight gain and final biomass respectively (Table 1). The weekly application of bioremediation agent increased the final biomass in $17 \%$ in the cultivation of juvenile shrimps. On the other hand, the inoculation of bioremediation agent incremented the weekly weight at $46.73 \%$ of shrimp. It is important to note that in Experiment 2 the feed conversion reduced significantly in the group treated with bioremediation agent $1.27 \pm 0.11$ and $1.36 \pm 0.26$ the weekly and fortnightly treatments respectively, and $56.7 \%$ of drop in the weekly treatment compared the control. The feed conversion in the control group was $1.99 \pm 0.66$. Regarding the survival were $72.5 \pm 5.54 \%$ in control, $71.65 \pm 4.56 \%$ in the week and $71.86 \pm 6.57 \%$ in the biweekly treatment no showed no significant differences between treatments.

The application of bioaugmentation agent in water of farming system-Experiment 2, rose significantly $(\mathrm{p}<0.05)$ survival and final biomass of farmed shrimp is $82.24 \pm 3.98 \%, 20,288.93 \pm 170.40 \mathrm{~g}$ and $92.72 \pm 2.96 \%, 22,588.58 \pm 54.36 \mathrm{~g}$ for control and Comambio ${ }^{\mathbb{B}}$ respectively, and the increase was $10.23 \%$ in Comambio ${ }^{\circledR}$ treatment whereas the survival rate increased in $11.34 \%$ of final biomass.

\section{Microbiological analysis}

The concentrations of total heterotrophic bacteria in the control

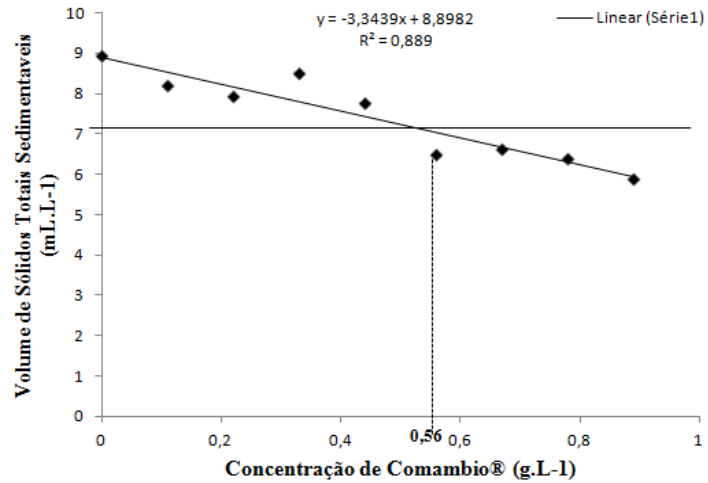

Figure 1: Variation of settleable solids (ssed) in water withdrawn from super-intensive culture of Litopenaeus vannamei with biofloc depending on the concentration of Comambio ${ }^{\circledR} 96$ hours after application. Line (-) is the second straight linear regression equation $Y=-3.3439 x+8.8982, R 2=0,889$, $p<0.01$. And " $Z$ " is the reference line that corresponds to the lower end of the confidence interval of the mean of control at $5 \%$ confidence level. SSed values below the reference line are statistically lower than the control group $(p<0.05)$.

\begin{tabular}{|c|c|c|c|}
\hline \multirow{2}{*}{ Zootechnical } & \multicolumn{3}{|c|}{ Treatments } \\
\cline { 2 - 4 } & Control & Weekly & Biweekly \\
\hline Weekly weight gain $(\mathrm{g})$ & $1.07 \pm 0.02^{\mathrm{a}}$ & $1.52 \pm 0.14^{\mathrm{b}}$ & $1.57 \pm 0.29^{\mathrm{b}}$ \\
\hline Feed conversion & $1.99 \pm 0.62^{\mathrm{b}}$ & $1.27 \pm 0.11^{\mathrm{a}}$ & $1.36 \pm 0.26^{\mathrm{a}}$ \\
\hline Final biomass (g) & $\begin{array}{c}308.41 \pm \\
38.37^{\mathrm{a}}\end{array}$ & $\begin{array}{c}361.01 \pm \\
15.95^{\mathrm{b}}\end{array}$ & $351.34 \pm 30.06^{\mathrm{b}}$ \\
\hline Livilihood rate (\%) & $72.5 \pm 5.54^{\mathrm{a}}$ & $71.65 \pm 4.56^{\mathrm{a}}$ & $71.86 \pm 6.57^{\mathrm{a}}$ \\
\hline
\end{tabular}

Label: Different letters between columns represent significant difference between treatments $(p<0.05) \backslash$

Table 1: Effect of application frequency of weekly and biweekly Comambio ${ }^{\circledR}$ on production indexes (mean \pm standard deviation) of Litopenaeus vannamei in super intensive system of cultivation with microbial flakes.

group in all trials was $3.14 \times 10^{5} \mathrm{CFU} / \mathrm{mL}$ to $8.11 \times 10^{5} \mathrm{CFU} / \mathrm{mL}$, while for bacterial counts type Vibrio spp. interval was $5.00 \times 10^{5} \mathrm{CFU} / \mathrm{mL}$ to $1.67 \times 10^{6} \mathrm{CFU} / \mathrm{mL}$. Meanwhile, the group treated with Comambio ${ }^{8}$ interval for the total heterotrophic bacterial counts ranging from $1.20 \times$ $10^{6} \mathrm{CFU} / \mathrm{mL}$ to $3.99 \times 10^{6} \mathrm{CFU} / \mathrm{mL}$, whereas and for counts of bacteria type Vibrio spp. concentrations ranged from $4.25 \times 10^{5} \mathrm{CFU} / \mathrm{mL}$ to 1.28 $\times 10^{6} \mathrm{CFU} / \mathrm{mL}$, there were no significant differences $(\alpha=0.05)$ between treatments as well as in both trials (Table 2).

\section{Physical and chemical variables in super intensive farming system with microbial flakes}

During the experimental phase in Experiment 2, the temperature was maintained in the range of $27.90 \pm 0.21$ to $28.50 \pm 031^{\circ} \mathrm{C}$ and minimum DO values were 5.80 and maximum of $6.30 \mathrm{mg} / \mathrm{L}$ in both the control and Comambio ${ }^{\circledR}$ in the treatment. There were no significant differences for the variables $\mathrm{O}_{2}, \mathrm{pH}$, salinity, transparency and SSed as can be seen in Table 3. Significant difference $(p<0.05)$ was observed in the water alkalinity amongst the treatment from the second week of cultivation. Alkalinity was higher in bioaugmentation agent treatment $\left(160.01 \pm 60.70 \mathrm{mg} / \mathrm{L} \mathrm{CaCO}_{3}\right)$ and $102.00 \pm 6.50 \mathrm{mg} / \mathrm{L}$ for the control group at the end of the experiment.

The concentration of $\mathrm{NH}_{4}-\mathrm{N}$ in Experiment 2 in water cultivation 


\begin{tabular}{|c|c|c|}
\hline \multirow{2}{*}{ Performance } & \multicolumn{2}{|c|}{ Treatments } \\
\cline { 2 - 3 } & Control & Comambio $^{\oplus}$ \\
\hline Final weight $(\mathrm{g})$ & $20.64 \pm 0.34$ & $20.64 \pm 0.34$ \\
\hline Final weight $(\mathrm{g})$ & $24.44 \pm 1.03$ & $24.81 \pm 0.63$ \\
\hline Weekly weight gain $(\mathrm{g})$ & $1.09 \pm 0.22$ & $1.07 \pm 0.23$ \\
\hline Final biomass $(\mathrm{g})$ & $20,288.93 \pm 170.4^{*}$ & $22,588.58 \pm 54.36$ \\
\hline Rate of livelihood $(\%)$ & $82.24 \pm 3.98^{*}$ & $92.72 \pm 2.96$ \\
\hline
\end{tabular}

Label: $\left(^{*}\right)$ statistical differences $(p<0.05)$.

Table 2: Biological indexes (mean \pm standard deviation) in the cultivation of super intensive Litopenaeus vannamei, with application to microbial flakes bioremediation $\left(\right.$ Comambio $\left.^{\circledR}\right)$ and without bioremediation (CONTROL)

did not differ between treatments, ranging from $0.04 \pm 0.03$ for the final value of $0.10 \pm 0.05 \mathrm{mg} / \mathrm{L}$ in the control group and $0.04 \pm 0.03$ to $0.12 \pm 0.012 \mathrm{mg} / \mathrm{L}$ in the group Comambio ${ }^{\circledR}$. Moreover, there was an increase of $\mathrm{NO}_{2}-\mathrm{N}$ in the first two weeks in treatment and declined gradually until the end of the experiment (Table 3 ). The concentration of $\mathrm{NO}_{2}-\mathrm{N}$ was higher $(\mathrm{p}<0.05)$, treatment with bioaugmentation agent after applying the product in farm ponds, $0.18 \pm 0.05 \mathrm{mg} / \mathrm{L}$ compared with $0.12 \pm 0.03 \mathrm{mg} / \mathrm{L}$ a control group. There was a dramatic rise in the concentration of nitrate $\left(\mathrm{NO}_{3}-\mathrm{N}\right)$ in both treatments, which started from initial values of $8.87 \pm 1.25$ to $23.27 \pm 4.60 \mathrm{mg} / \mathrm{L}$ in Comambio ${ }^{\circledR}$ and $23.80 \pm 2.87 \mathrm{mg} / \mathrm{L}$ in control and there was significant difference between treatments. The concentration of orthophosphate ranged from $3.40 \pm 0.20 \mathrm{mg} / \mathrm{L}$ to $3.66 \pm 0.23 \mathrm{mg} / \mathrm{L}$ in the control treatment and 3.40 \pm 0.20 to $3.34 \pm 0.35 \mathrm{mg} / \mathrm{L}$ in $\mathrm{Comambio}^{\circledR}$ treatment which did not show significant difference between the both treatments.

With regard to solids (TSS) the findings demonstrates an increase in concentration over cultivation in both treatments. The average values of TSS increased dramatically from $501.07 \pm 32.67 \mathrm{mg} / \mathrm{L}$ to $1558 \pm$ $532.24 \mathrm{mg} / \mathrm{L}$ in Comambio ${ }^{\circledR}$ treatment. On the other hand, the control group showed a sharp rise from $501.07 \pm 32.67 \mathrm{mg} / \mathrm{L}$ to $844.50 \pm 68.71$ $\mathrm{mg} / \mathrm{L}$. The concentration was significantly higher in the treatment bioaugmentation agent.

The concentration of SSF was statistically higher $(\mathrm{p}<0.05)$ in Comambio $^{\circledR}$ group compared to the control one (Table 3). The final values of $1120.80 \pm 378.58 \mathrm{mg} / \mathrm{L}$ in treatments with Comambio ${ }^{\circledR}$ were significantly higher than $428 \pm 39.22 \mathrm{mg} / \mathrm{L}$ that observed in the control. On the other hand, the SSV showed no statistically differences between treatments as shown in Table 3. In the control, SSV ranged from 211.67 $\pm 55.69 \mathrm{mg} / \mathrm{L}$ to $416.00 \pm 33.51 \mathrm{mg} / \mathrm{L}$ and group Comambio ${ }^{\circledR}$ ranged from $211.67 \pm 55.69$ to $432.00 \mathrm{mg} / \mathrm{L} \pm 76.18 \mathrm{mg} / \mathrm{L}$.

Figure 2 illustrates the influence of Comambio ${ }^{\circledR}$ SSed in the volume of water present in cultivation. The volume of SSed was significantly $(\mathrm{p}<0.05)$ lower in the group of Comambio ${ }^{\circledR}$, the period between the third and the seventeenth day of cultivation. The greatest decline of solids was observed after the second application of the product in the second week of cultivation, with a drop of $63.4 \%$ in the volume of SSed $9.92 \pm 0.49$ to $3.58 \pm 0.92 \mathrm{~mL} / \mathrm{L}$ Comambio ${ }^{\circledR}$ treatments. After the third week of cultivation the reduction of SSed was decreasing by the end of cultivation, when the volume of solids was $13.80 \pm 2.60 \mathrm{~mL} / \mathrm{L}$ in the treatment product and $16.60 \pm 3.20 \mathrm{~mL} / \mathrm{L}$. There was no significant difference in the volume of SSed in the last week of cultivation.

The BOD in early cultivation stage was $13.31 \pm 1.55 \mathrm{mg} / \mathrm{L}$ in both treatments and declined substantially by $70.2 \%$ in the treatment Comambio $^{\circledR}$ and $17.4 \%$ in the control treatment. The BOD was significantly $(p<0.05)$ lower at the end of the trial, $3.1 \pm 1.55 \mathrm{mg} / \mathrm{L}$, in dealing with bioaugmentation agent compared with the control group that was $10.95 \pm 0.63 \mathrm{mg} / \mathrm{L}$ as can be seen in Figure 3 .

The average TOC during the experimental period ranged from baseline $19 \pm 0.44 \mathrm{mg} / \mathrm{L}$ to $29 \pm 0.12 \mathrm{mg} / \mathrm{L}$ in control and final value of $19 \pm 29$ to $0.10 \pm 0.20 \mathrm{mg} / \mathrm{L}$ in Comambio ${ }^{\circledR}$ treatment and were no observed significant difference between treatments.

\section{Discussion}

The data from Comambio ${ }^{\circledR}$ in sea water "crystal" suggest an increased amount of total suspended and fixed solids which may be harmful to use. The increase in alkalinity of the water due to use of the product $\left(8.2 \mathrm{mg} / \mathrm{L} \mathrm{CaCO}_{3}\right)$ could be discussed with reference to the material of microorganisms in the product which were not supplied and approved by the manufacturer.

The increased concentration of bioaugmentation agent in water containing microbial flakes resulted in a higher proportion of microorganisms in the product, which probably must have caused higher microbial activity in the system resulting in greater decline of SSed. According to Jiao et al. [22] the high concentration of microorganisms through the bioaugmentation agent is vital in the process of bioaugmentation agent to maintain the necessary concentration of beneficial microorganisms in the system that is intended to remedy. The author claims that this happens because many bacteria have a gene expression mechanism for coordinating; a process called "quorum-sensing" that regulates the responses and processes of production of phenotypes such as enzymes production, toxins and biofilm formation [23].

The influence of bioaugmentation agents on growth and survival of cultured shrimp has been reported by other authors $[13,24]$. The use of Comambio ${ }^{\mathbb{R}}$, showed no harmful effects to the raised animals since they showed positive growth and no physiological change was noticed after the application continued. Its incorporation in the farming system showed improvement in biological indexes of the animals under super intensive condition. Despite the fact that the bioaugmentation agent was not tested in super intensive cultivation, Janeo et al. [24] observed a similar result in intensive system of Peaeus monodon after applying bioaugmentation agent containing Nitrobacter and Bacillus (approximately $3 \times 10^{9} \mathrm{CFU} / \mathrm{g}$ ) and lipases and proteases applied in doses de100 g/ha, $150 \mathrm{~g} / \mathrm{ha}, 200 \mathrm{~g} / \mathrm{ha}$ and $300 \mathrm{~g} / \mathrm{ha}$. The impact of bioremediate in survival of cultured shrimp verified this trial might be related to its contribution into composition microbial composition of the gastrointestinal tract and the shrimp cultivation environment.

In spite of the fact that the study has not used bacteria indigenous to the cultivation of prawns, Comambio ${ }^{\circledR}$ presents in its composition Bacillus spp. Bacteria of the genus Bacillus were able to reduce the amount of pathogens present in water cultivation, as well as lower concentrations of nutrients in the water, thus acting as bioaugmentation agent and as bio-control [25].

The other microorganisms also found in products used as Aspergillus niger and Trichoderma sp. are known for their ability to secrete digestive enzymes like amylases, proteases and celluloses for the environment [26], which may have contributed to increased the growth and survival of shrimp cultivation. Janeo et al. [24], reported results in increased growth in $P$. monodon by applying a bioaugmentation agent in water cultivation that had bacteria of the genus Nitrobacter and Bacillus well as lipases and proteases.

Bioremediation has been reported as a solution to control pathogenic bacteria in aquaculture crops [24,27]. In this study, the effect 
Citation: Salência HR, Mouriño JLP, Ferreira GS, Arantes RF, Ubert M, et al. (2016) A Bioaugmentation Agent in Super Intensive Marine Shrimp Farming System with Zero Water Exchange. J Aquac Res Development 7: 406. doi:10.4172/2155-9546.1000406

Page 5 of 7

\begin{tabular}{|c|c|c|c|c|c|c|c|c|c|}
\hline \multirow[b]{2}{*}{$\begin{array}{c}\text { Chemical and physical } \\
\text { Characteristics }\end{array}$} & \multicolumn{5}{|c|}{ CONTROL weeks } & \multicolumn{4}{|c|}{ Comambio $®$ Weeks } \\
\hline & 0 & 1 & 2 & 3 & 4 & 1 & 2 & 3 & 4 \\
\hline $\mathrm{DO}(\mathrm{mg} / \mathrm{L})$ & $5.9 \pm 0.28$ & $5.9 \pm 0.08$ & $5.8 \pm 0.09$ & $5.8 \pm 0.09$ & $5.8 \pm 0.08$ & $5.9 \pm 0.28$ & $5.8 \pm 0.16$ & $5.8 \pm 0.14$ & $5.80 \pm 0.13$ \\
\hline Temperature $\left({ }^{\circ} \mathrm{C}\right)$ & $27.09 \pm 0.32$ & $27.9 \pm 0.27$ & $27.9 \pm 0.23$ & $27.9 \pm 0.22$ & $27.9 \pm 0.21$ & $27.9 \pm 0.32$ & $28.1 \pm 0.30$ & $28.01 \pm 0.31$ & $27.90 \pm 0.30$ \\
\hline $\mathrm{pH}$ & $7.8 \pm 0.08$ & $7.8 \pm 0.05$ & $7.8 \pm 0.06$ & $7.8 \pm 0.08$ & $7.8 \pm 0.09$ & $7.8 \pm 0.12$ & $7.8 \pm 0.10$ & $7.8 \pm 0.10$ & $7.80 \pm 0.01$ \\
\hline Salinity (g/ L ) & $3.20 \pm 0.12$ & $3.31 \pm 0.12$ & $3.26 \pm 0.36$ & $3.25 \pm 0.47$ & $3.22 \pm 0.50$ & $3.32 \pm 0.09$ & $3.25 \pm 0.21$ & $3.23 \pm 0.27$ & $3.21 \pm 0.30$ \\
\hline $\mathrm{NH} 4-\mathrm{N}(\mathrm{mg} / \mathrm{L})$ & $0.04 \pm 0.03$ & $0.12 \pm 0.04$ & $0.14 \pm 0.04$ & $0.10 \pm 0.05$ & $0.10 \pm 0.05$ & $0.13 \pm 0.07$ & $0.14 \pm 0.05$ & $0.11 \pm 0.05$ & $0.12 \pm 0.05$ \\
\hline NO 2-N (mg/L ) & $0.09 \pm 0.02$ & $0.12 \pm 0.03$ & $0.11 \pm 0.06$ * & $0.07 \pm 0.01$ & $0.04 \pm 0.01$ & $0.18 \pm 0.05$ & $0.16 \pm 0.08$ & $0.10 \pm 0.05$ & $0.06 \pm 0.02$ \\
\hline NO 3-N (mg/ L ) & $8.87 \pm 1.24$ & $12.3 \pm 0.68$ & $16.50 \pm 2.90$ & $17.2 \pm 6.10$ & $23.8 \pm 2.80$ & $14.3 \pm 2.10$ & $11.3 \pm 1.69$ & $22.7 \pm 3.55$ & $23.40 \pm 4.60$ \\
\hline PO 4-P (mg/ L ) & $3.40 \pm 0.20$ & $3.71 \pm 0.20$ & $3.27 \pm 0.26$ & $3.38 \pm 3.12$ & $3.66 \pm 0.23$ & $3.70 \pm 0.16$ & $3.26 \pm 0.26$ & $3.26 \pm 0.15$ & $3.34 \pm 0.35$ \\
\hline $\mathrm{CaCO} 3 \mathrm{mg} / \mathrm{L}$ & $120 \pm 0.10$ & $98 \pm 3.80$ & $106 \pm 7.90$ & $115 \pm 3.50$ & $102 \pm 6.50$ & $100 \pm 3.30$ & $147 \pm 28.5$ & $168 \pm 48.70$ & $160 \pm 60.70$ \\
\hline Transparency $(\mathrm{cm})$ & $15.10 \pm 0.05$ & $\begin{array}{c}14.40 \pm \\
1.20\end{array}$ & $13.7 \pm 0.90$ & $13.10 \pm 1.40$ & $12.5 \pm 1.00$ & $11.2 \pm 0.0$ & $10.8 \pm 1.20$ & $10.1 \pm 1.40$ & $9.70 \pm 1.30$ \\
\hline Turbidity (NTU) & $\begin{array}{c}104.30 \pm \\
24.80\end{array}$ & $\begin{array}{c}104.30 \pm \\
24.80\end{array}$ & $\begin{array}{l}125.7 \pm \\
36.10\end{array}$ & $\begin{array}{l}140.19 \pm \\
44.10\end{array}$ & $\begin{array}{l}161.9 \pm \\
45.10^{*}\end{array}$ & $\begin{array}{l}174.8 \pm \\
49.50^{*}\end{array}$ & $179.9 \pm 37.6$ & $217.2 \pm 55.40$ & $\begin{array}{c}277.03 \pm \\
64.30\end{array}$ \\
\hline SST (mg/L ) & $\begin{array}{l}501.07 \pm \\
32.67\end{array}$ & $\begin{array}{c}569.80 \pm \\
91.60^{*}\end{array}$ & $\begin{array}{l}689.8 \pm \\
44.40^{*}\end{array}$ & $\begin{array}{l}642.0 \pm \\
63.00^{*}\end{array}$ & $\begin{array}{l}844.5 \pm \\
68.70^{*}\end{array}$ & $\begin{array}{l}854.3 \pm \\
126.20\end{array}$ & $994.8 \pm 142.70$ & $\begin{array}{c}1223.5 \pm \\
380.20\end{array}$ & $\begin{array}{l}1558.80 \pm \\
553.20\end{array}$ \\
\hline $\mathrm{SSF}(\mathrm{mg} / \mathrm{L})$ & $\begin{array}{l}289.01 \pm \\
28.53\end{array}$ & $\begin{array}{c}321.30 \pm \\
65.90^{*}\end{array}$ & $\begin{array}{l}386.6 \pm \\
30.50^{*}\end{array}$ & $\begin{array}{l}402.1 \pm \\
245.40^{*}\end{array}$ & $\begin{array}{l}428.5 \pm \\
39.20^{*}\end{array}$ & $\begin{array}{c}566.0 \pm \\
79.91\end{array}$ & $670.6 \pm 142.10$ & $\begin{array}{l}809.3 \pm \\
344.20\end{array}$ & $\begin{array}{c}1120.80 \pm \\
376.50\end{array}$ \\
\hline $\mathrm{SSV}(\mathrm{mg} / \mathrm{L})$ & $\begin{array}{l}204.33 \pm \\
35.75\end{array}$ & $\begin{array}{l}248.5 \pm \\
34.70\end{array}$ & $\begin{array}{c}303.2 \pm \\
17.40\end{array}$ & $344.0 \pm 44.50$ & $\begin{array}{l}416.0 \pm \\
33.50\end{array}$ & $\begin{array}{l}288.3 \pm \\
69.30\end{array}$ & $324.0 \pm 42.80$ & $\begin{array}{l}323.6 \pm \\
111.40\end{array}$ & $\begin{array}{l}432.20 \pm \\
76.20\end{array}$ \\
\hline SSed (mL/L ) & $8.41 \pm 0.07$ & $9.3 \pm 1.10$ & $11.4 \pm 1.10$ & $13.9 \pm 2.40$ & $16.6 \pm 3.10$ & $8.4 \pm 1.10^{*}$ & $6.9 \pm 1.30^{*}$ & $10.9 \pm 3.10^{*}$ & $13.80 \pm 2.60$ \\
\hline
\end{tabular}

Label: $\left({ }^{*}\right)$ statistical differences between treatments in the same week cultivation $(p<0.05)$.

Table 3: Chemical and physical characteristics of water (mean \pm standard deviation) during the experimental cultivation of super intensive marine shrimp, Litopenaeus vannamei with bioflocs with application of microbial bioremediation (Comambio ${ }^{\circledR}$ ) and without bioremediation (Control). The data on weeks zero (0) correspond to analysis performed in the two treatments at the beginning of the experiment.

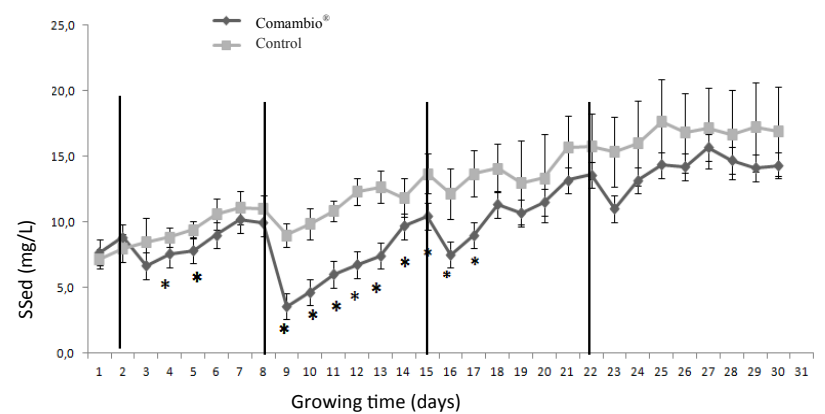

Figure 2: Effect of Comambio ${ }^{\circledR}$ in the volume of settleable solids (SSed) (mean \pm standard deviation) during the growing array of Litopenaeus vannamei in super-intensive system with zero water exchange. $\left({ }^{*}\right)$ Average statistically different. Line () is related to application of bioremediation $(p<0.05)$

was not observed the effect of bioaugmentation agent in concentrations of bacteria of the genus Vibrio since no selection was performed to investigate the inhibitory capacity of pathogens in the product and choice of strains. On the other hand, the method of counting bacteria based on applied microbiology underestimates the quantitative and qualitative measurement of populations of heterotrophic bacteria and may interfere with the interpretation of results of bioremediation by restricting interpretation of biotic and abiotic factors [28]. These findings could be interpreted using methods such as microbial ecology, total extraction of DNA, bloom microscopy among others.



Figure 3: Data of Biochemical Oxygen Demand (mean \pm standard deviation) in super intensive culture of Litopenaeus vannamei with biofloc microbial bioremediation with and without bioremediation at the beginning and at the end of cultivation. $\left(^{*}\right)$ Represents statistical difference $(p<0.05)$.

The entry of bioremediation in Comambio ${ }^{\circledR}$ treatment may have contributed to the increase in alkalinity as the need to use lime during cultivation was lower than the control material probably due to the viability of microorganisms of the product (not supplied by the manufacturer) that perhaps contained materials that interfere with the alkalinity.

The reduction of alkalinity in controls might be related to the occurrence of nitrification since nitrate increase was observed in the culture [5]. 
The reduction of SSed during cultivation immediately after the addition of Comambio ${ }^{\circledR}$ suggests the existence of specific microorganisms in the product relative to the substrate cultivation system since the settling characteristics of sludge in microbial systems are directly affected by microbial composition that exists in the water [29].

The microbiological composition of Comambio ${ }^{\circledR}$ contributed to the reduction of settle able solids found in cultivation system. Similar results were reported by Primavera, Lavilla-Pitogo, Ladji and Dela Peña [30], whose observed a reduction of sludge formed in nurseries producing intensive cultivation of $P$. monodon that used commercial products containing bacteria Nitrosomonas, Sulfur Bacteria, Bacillus sp. and/or enzymes (proteases, celluloses) for quality control in concentrations defined according to the specifications of each product used by the producer.

Although by the end of the growing concentration of SSF did not interfere on the performance of farmed shrimp, there was not available scientific research describing shrimp growth at higher concentrations than those of SSF with values referenced below $1000 \mathrm{~g} / \mathrm{L}$ [31].

The content of VSS and TOC concentration did not differ statistically between treatments. This suggests that there must have had no reduction of the amount of organic matter with the addition of bioaugmentation agent. However, Wang and $\mathrm{He}$ [14] reported reduction of TOC in the sediment ponds intensive farming of $L$. vannamei after the application of a commercial bioaugmentation agent containing the $10 \times 10 \mathrm{CFU} / \mathrm{g}$ from Bacillus sp. Nitrosomonas sp. Nitribacter sp. and Lactobacillus.

However, the data point to lower the BOD value in the treated group at the end of the trial. This reduction of BOD as a result of application of the product Comambio ${ }^{\circledR}$ may be an indication of the reduction in the fraction of organic matter. Similar results have been reported by Jiao et al. [12], who reported an increase in the reduction of BOD treatment system with application of wastewater bacterial strains as well as the research conducted by Wang and He [14] also observed a decline of BOD and COD in cultured shrimp with application of products containing bacteria the genus Bacillus sp. Nitrosomonas sp. Nitribacter sp. and Lactobacillus.

Higher values in the concentration of nitrite in the first week may indicate the mineralization of organic matter immediately after the addition product bioremediation, while the concentration of dissolved mineral matter in the form of orthophosphate and nitrate did not differ between treatments [32]. Mcintosh [33] also observed no difference in nitrate concentration after application of probiotic in shrimp farming. However, Kuhn, Drahos, Marsh and Flick Jr. [34] claim reduction of ammonia and nitrite as a result of product application bioremediation in tanks of intensive cultivation of marine shrimp.

The dynamics of organic matter and mineralization processes are still poorly understood in super intensive farming system [5,35]. The application of the product may have caused increased microbial biomass in growing through the degradation of organic matter helping to change the quality and diversity of the microbiota [36].

As a recommendation to the understanding of the relations of microorganisms into the super intensive system with bioflocs in relation to microbial bioaugmentation product, it is of extreme importance to use molecular tools for microbial identification, and their relationship with the growth performance as well as physical and chemical parameters of water for cultivation. Another mechanism that should be taken into consideration in future studies is the design of clarifiers to remove suspended material and solids because according to these results, this can be used in conjunction with bioaugmentation products that does not require huge volumes for effluents treatment since they reduced the volume of filtered solid, suggesting an increased rate of sedimentation which was not measured in this test.

It is concluded that the bioaugmentation can be applied in the cultivation of shrimp with zero water exchange, given that its use had immediate effect in reducing the volume of settle able solids. Furthermore, the effects of continued use of bioremediation on the characteristics of the microbial community in the water for cultivation should be studied taking into account that its weekly application has contributed significantly to the growth of shrimp and consequently has increased the final biomass.

\section{Acknowledgement}

The authors thank the International Fellowship from the Ford Foundation, Represented in Mozambique by the African-American Institute, the graduate student stipend granted, the Ministry of Fisheries in Mozambique for the incentive, the Marine Laboratory of Cameroon for the help and facilities used mantain of the shrimp used in the research.

The Genearch LTD company for providing the strain of animal use SPF (specific pathogen free), Guabi company for providing the feed used in the experiments and the Comam Comercio Biorremediação LTDA firm for providing assistance and Comambio ${ }^{\circledR}$ and financial support for lab analysis as well as the reviewer of the manuscript.

Dr. Luis Hamilton, Sanitary Engineer Epagri researcher. To Cnpq for granting part of the process $n^{\circ} 472690 / 2011-4$ (universal call 14/2011) and postdoctoral scholarship grant and to the researcher José Luiz P. Mouriño (process 303503/2011-4)

\section{References}

1. FAO (2010) Fisheries Gateway. Aquaculture. In: FAO Fisheries and Aquaculture Department.

2. NACA/FAO (2001) In: Subasinghe RP Bueno P Phillips MJ, Hough $C$ McGladdery SE, et al. (eds.) (2000) Technical proceedings of the Conference on Aquaculture in the Third Millenium. Bangkok, Thailand, Febrauary 20-25, 2000

3. Gutierrez-Wing MT, Malone RF (2006) Biological filters in aquaculture: Trends and research directions for freshwater and marine applications. Aquacultural Engineering 34: 163-171

4. Avnimelech Y, Mozes N, Weber B (1992) Effects of aeration and mixing on nitrogen and organic matter transformations in simulated fish ponds. Aquacultural Engineering 11: 157-169.

5. Hargreaves JA (2006) Photosynthetic suspended-growth systems in aquaculture. Aquacultural Engineering. 34: 344-363.

6. Avnimelech Y (2006) Bio-filters: The need for an new comprehensive approach Aquacultural Engineering 34: 172-178.

7. Avnimelech $Y$ (2007) Feeding with microbial flocs by tilapia in minimal water discharge bio-flocs technology ponds. Aquaculture 264: 140-147.

8. OIE (2010) 78th General Session: strategies reinforced. Bulletin No 4.

9. Browdy CL, Bratvold D, Stokes AD, Mclntosh RP (2001) Perspectives on the biotechnology 51: 113-154.

10. Burford MA, Thompson PJ, McIntosh RP, Bauman RH (2003) Improvement of the probiotic effect of microorganisms by their combination with maltodextrins, fructo-oligosaccharides and polyunsaturated fatty acids. Br J Nutr 88: 95-99.

11. Zhou Q, LiK, Jun X, Bo L (2009) Role and functions of beneficial microorganisms in sustainable aquaculture. Bioresource Technology 100: 3780-3786.

12. Jiao Y, Jin WB, Zhao QL, Zhang GD, Yan Y, et al. (2009) Transformation of nitrogen and distribution of nitrogen-related bacteria in a polluted urban stream. Water Sci. Technol 60: 1597-1605.

13. Moriarty DJW (1998) Control of luminous Vibrio species in penaeid aquaculture ponds. Aquaculture 164: 351-358. 
Citation: Salência HR, Mouriño JLP, Ferreira GS, Arantes RF, Ubert M, et al. (2016) A Bioaugmentation Agent in Super Intensive Marine Shrimp Farming System with Zero Water Exchange. J Aquac Res Development 7: 406. doi:10.4172/2155-9546.1000406

14. Wang Y, He Z (2009) Effect of probiotics on alkaline phosphatase activity and nutrient level in sediment of shrimp, Penaeus vannamei, ponds. Aquaculture 287: 94-97.

15. Eat Commerce and Bioremediation LTDA Services ( 2010) Analysis Report microbiological product Comambio. [leaflet] April 2010 ed .: Eat - Commerce and bioremediation LTDA services. Campinas, São Paulo, Brazil.

16. American Public Health Association (2005) Standard methods for the examination of water and wastewater. 21st. APHA: Washington, USA.

17. Van Wyk P, Scarpa J (1999) Water quality and management. In: Van Wyk P, Davis-Hodgkins M, Laramore R, Main KL, Moutain J, Scarpa J (Eds.). Farming marine shrimp in recirculating freshwater systems. Florida department of agriculture and consumer services, Tallahassee, pp: 128-138.

18. Ebeling JM, Timmons MB, Bisogni JJ (2006) Engineering analysis of the stoichiometry of photoautotrophic, autotrophic and heterotrophic removal of ammonia-nitrogen in aquaculture systems. Aquaculture 257: 346-358.

19. APHA (1995) American Public Health Association Water Works Association, Water Pollution Control Association. Standard Methods for Examination of Water and Wastewater, 19th ed. American Public Health Association, Washington, DC, USA.

20. Madigan MT, Martinko J, Parker J (2002) Brock Biology of Microorganisms. Printece Hall, USA

21. Zar JH (2001) Biostatistical analysis. Pearson Education, USA

22. Jiao Y, Zhao Q, Jin W, Hao X, You S (2011) Bioaugmentation of a biological contact oxidation ditch with indigenous nitrifying bacteria for in situ remediation of nitrogen-rich stream water. Bioresource Technology 102: 990-995.

23. Defoirdt T, Boon N, Bossier P, Verstraete W (2004) Disruption of bacterial quorum sensing: an unexplored strategy to fight infections in aquaculture. Aquaculture 240: 69-88.

24. Janeo R, Corre Jr. VL, Sakata T (2009) Water quality and phytoplankton stability in response to application frequency of bioaugmentation agent in shrimp ponds. Aquacultural Engineering 40: 20-125.

25. Lalloo R, Ramchuran S, Ramduth D, Gorgens J, Gardiner N (2007) Isolation and selection of Bacillus spp. as potential biological agents for enhancement of water quality in culture of ornamental fish. Journal of Applied Microbiology 103: 1471-1479.
26. Weibe MG (2003) Stable production of recombinant proteins in filamentous fungi - problems and improvements. Mycology 17: 140-144.

27. Moriarty DJW (1999) Disease control in shrimp aquaculture with probiotic bacteria. In: Bell CR, Brylinsky $M$, Johnson-Green $P$ (Eds.), Microbial Biosystems: New Frontiers: Proceedings of the 8th International Symposium on Microbial Ecology. Atlantic Canada Society for Microbial Ecology, Halifax Canada.

28. Head IM (1998) Bioremediation: towards a credible technology. Microbiology 144: $599-408$.

29. Crab R, Avnimelech Y, Defoirdt T, Bossier P, Verstraete W (2007) Nitrogen removal techniques in aquaculture for a sustainable production. Aquaculture 270: $1-14$

30. Primavera JH, Lavilla-Pitogo CR, Ladja JM, Dela Peña MR (1993) Survey of Chemical and Biological Products used in Intensive Prawn Farms in the Philippines. Marine Pollution Bulletin 26: 35-40.

31. Ray AJ, Lewis BL, Browdy CL, Leffler JW (2010) Suspended solids removal to improve shrimp (Litopenaeus vannamei) production and an evaluation of a plant-based feed in minimalexchange superintensive culture systems. Aquaculture 299: 89-98.

32. Hargreaves JA (1998) Nitrogen biogeochemistry of aquaculture ponds Aquaculture 166: 181-212.

33. Mcintosh D, Samocha TM, Jones ER, Lawrence AL, Mckee DA, et al. (2000) The effect of a commercial bacterial supplement on the high-density culturing of Litopenaeus vannamei with a low-protein diet in an outdoor tank system and no water exchange. Aquacultural Engineering 21: 215-227.

34. Kuhn DD, Drahos DD, Marsh L, Flick Jr. GL (2010) Evaluation of nitrifying bacteria product to improve nitrification efficacy in recirculation aquaculture systems. Aquacultural Engineering 43: 78-82.

35. Vinatea L, Gálvez AO, Browdy CL, Stokes A, Venero J, et al. (2010) Photosynthesis, water respiration and growth performance of Litopenaeus vannamei in a super-intensive raceway culture with zero water exchange: Interaction of water quality variables. Aquacultural Engineering 42: 17-24.

36. Avnimelech $Y$ (1999) Carbon/nitrogen ratio as a control element in aquaculture systems. Aquaculture 176: 227-235. 